\title{
Література
}

1. Бацевич Ф. С. Словник термінів міжкультурної комунікації / Ф. С. Бацевич. К. : Довіра, 2007. - 205 с. 2. Биков В. Ю. Теоретико-методологічні засади моделювання навчального середовища педагогічних систем відкритої освіти / В. Ю. Биков // Наукові записки. Серія: Педагогічні науки. - Кіровоград : РВВ КДПУ ім. В. Винниченка. - 2008. - Випуск 77. - Частина 1. - С. 3-12. 3. Грушевицкая Т. Г. Основы межкультурной коммуникации : [учебник для вузов] / Т. Г. Грушевицкая, В. Д. Попов, А. П. Садовин; под ред. А. П. Садохина. - М. : Юнити-Дана, 2003. 352 с. 4. Концепція мовної освіти 12-річної школи // Дивослово. - 2002. - № 8. - С.5965. 5. Подранецька Н. Застосування проектних технологій на уроках української мови та літератури як один із напрямків розвитку мовної особистості / Н. Подранецька // Українська мова і література в школі. - 2006. - № 4. - С. 22-25. 6. Пометун О. Активні й інтерактивні методи навчання: до питання про диференціацію понять / О. Пометун // Шлях освіти. - 2004. - № 3. - С. 10-15. 7. Селіванова О. О. Сучасна лінгвістика: напрями та проблеми : [підручник] / О. О. Селіванова. - Полтава : Довкілля-К, 2008. - 712 с. 8. Селіванова О. О. Сучасна лінгвістика: термінологічна енциклопедія / О. О. Селіванова. - Полтава : Довкілля-К, 2006. - 716 с. 9. Философский словарь / под ред. И. Т. Фролова. - М. : Политиздат, 1987. - 590 c. 10. Языкознание. Большой энциклопедический словарь/гл. ред. В. Н. Ярцева. - М. : Большая Российская энциклопедия, 1998. - 685 с.

УДК 378.147(07)+371:811

Тетяна Мішеніна

\section{ЗМІСТ КУЛЬТУРОЛОГІЧНОГО СКЛАДНИКА У ФАХОВІЙ ПІДГОТОВЦІ МАЙБУТНІХ УЧИТЕЛІВ ФІЛОЛОГІЧНИХ СПЕЦІАЛЬНОСТЕЙ}

Мішеніна Т. М. Зміст культурологічного складника у фаховій підготовці майбутніх учителів філологічних спеціальностей.

У статті здійснено спробу розроблення змісту культурологічного складника у фаховій підготовці майбутніх філологів, об'єктивований у навчальних дисциплінах циклу гуманітарної й соціально-економічної підготовки. Розкрито сутність компаративного підходу до вивчення фахових дисциплін, який розуміється як розгляд мистецьких явищ (образотворчих, лінгвістичних і літературних) у межах культури / культур. Наведено приклади компаративних методик у змісті дисципліни «Лінгвістичний аналіз тексту».

Ключові слова: культурологічний складник, майбутні вчителі філологічних спеціальностей, дидактична компетентність, культурологічна компетенція, аксіологічна компетенція, компаративний підхід.

Мишенина T. M. Содержание культурологической составляющей в профессиональной подготовке будущих учителей филологических специальностей.

В статье сделана попытка разработки содержания культурологической составляющей в профессиональной подготовке будущих филологов, который реализуется в учебных дисциплинах цикла гуманитарной и социально-экономической подготовки. Раскрыта сущность компаративного подхода к изучению специальных дисциплин, которая понимается как рассмотрение явлений искусства (художественнографических, лингвистических и литературных) в рамках культуры / культур. Приведены примеры компаративных методик в содержании дисциплины 
«Лингвистический анализ текста».

Ключевые слова:культурологическая составляющая, будущие учителя филологических специальностей, дидактическая компетентность, культурологическая компетенция, аксиологическая компетенция, компаративный подход.

Mishenina T. M. Content of cultural urological component in training future teachers philological specialties.

The paper attempts to establish the content of cultural urological component in training future philologists, which is implemented in educational disciplines cycle of humanitarian and socio-economic training. The essence of the comparative approach to the study of special subjects, which is understood as the examination of phenomena of art (art-graphic, linguistic and literary) within the culture / cultures. The examples of comparative methods in the content of the discipline "Linguistic analysis of the text»"

Keywords: cultural studies component, future teachers' philological specialties didactic competence, cultural competence, axiological competence, comparative approach.

Провідна роль в оновленні системи освіти належить вищим педагогічним навчальним закладам, оскільки саме в таких умовах задаються методологічні, змістові та технологічні параметри освіти на всіх їі рівнях, формується педагогічне мислення і професіоналізм майбутнього вчителя. Нові підходи до забезпечення фаховоїпідготовки вчителя філологічних спеціальностей відображають усвідомлення фундаментальної залежності суспільних перспектив, що закладаються його педагогічною освітою.

Інструментальні можливості педагогічної діяльності в умовах інформаційного освітнього середовища містять у собі як потенціал гуманну підтримку індивідуального розвитку особистості в навчально-виховному середовищі; водночас слід попередити можливість авторитарного нівелювання ії особистісної неповторності шляхом забезпечення гуманності організованого вчителем педагогічного процесу. Останнє зумовлює необхідність перегляду пріоритетів у системі фахової підготовки вчителя філологічних спеціальностей, де, окрім формування спеціальних компетенцій, набуває важливості становлення суб'єктної позиції майбутнього педагога. Одним з основних чинників забезпечення здатності студента філологічного факультету до творчого саморозвитку є його загальнокультурна освіченість, потреба в якій визначена вимогами сучасного ринку праці.

Зазначена тенденція дістала продуктивну реалізацію шляхом уведення до системи фахової підготовки вчителя філологічних спеціальностей культурологічної освіти, спрямованої на забезпечення процесів трансляції загальнокультурного досвіду людства, вкорінення його в особистісному духовному світі студентів.

Культурологічна освіта майбутніх учителів філологічних спеціальностей:

1) є об'єктивованою у вищих навчальних закладах нормативними дисциплінами: «ІІторія України та історія української культури», «Культурологія», «Релігієзнавство» циклу гуманітарної й соціально-економічної підготовки студентів філологічних спеціальностей; «Вступ до українознавства», «Етногенез українців», «Етнодемографічна історія України», «Етнолінгвістика», «Основи етнодержавознавства», «Основи лінгвокультурології» варіативної частини циклу підготовки освітньо-кваліфікаційного рівня «бакалавр» зі спеціалізацією «Українознавство»;

2) позитивно впливає на забезпечення готовності майбутніх фахівців виконувати соціокультурні функції професії вчителя філологічних спеціальностей, становлення 
всіх складників дидактичної компетентності.

Соціальне значення культурологічної освіти актуалізується в умовах педагогічного університету, який сприяє розвитку широкої загальнокультурної освіченості майбутніх учителів філологічних спеціальностей, а також становленню системності дидактичного мислення. Культурологічна освіта $\epsilon$ також одним із провідних чинників підвищення соціального статусу вчителя як висококультурної особистості й енциклопедично освіченого фахівця.

Аналіз освітнього процесу у вищих навчальних закладах дозволяє окреслити суперечності між теоретично декларованою метою формування цілісної особистості майбутнього вчителя і збереженням предметоцентрованої моделі професійної освіти на практиці; між орієнтацією педагогічного університету на фундаментальне загальнокультурне знання та нереалізованістю його у професійно-педагогічній діяльності майбутніх фахівців. Розв'язання цих суперечностей актуалізує проблему теоретичного і методичного забезпечення культурологічної освіти студентів у вищих навчальних закладах як засобу формування цілісності особистісної та дидактичної компетентності майбутніх учителів філологічних спеціальностей.

Культурологічна освіта майбутніх учителів у педагогічно організованій системі формування фахової підготовки досліджувалась за такими конкретними аспектами [1; $2 ; 4 ; 7]$ : культура як предмет культурологічної освіти (Ю. Афанасьєв, Є. Бистрицький, Б. Срасов, М. Каган, С. Кримський, Е. Маркарян, В. Межуєв, Е. Орлова, Ю. Павленко, М. Попович, В. Розін, А. Флієр); культурологічна підготовка студентів вищих навчальних закладів (Г. Васянович, Г. Дегтярьова, М. Лещенко, Л. Руденко, О. Щолокова); фахово спрямовані моделі культурологічної підготовки фахівця (Л. Кондрацька, В. Маслов, Т. Рейзенкінд); методичне забезпечення окремих компонентівкультурологічної освіти студента (В. Бутенко, А. Капська, Г. Падалка, О. Рудницька, Г. Філіпчук).

Аналіз методологічної та методичної літератури з досліджуваної теми, а також практичного досвіду викладання культурологічних курсів у вищих навчальних закладах дозволяє зробити висновок, що в численних і вагомих за теоретичними i прикладними результатами надбаннях педагогічної науки залишається поза увагою проблема комплексного дослідження теорії та практики культурологічної освіти як процесу й результату педагогічно організованого залучення майбутнього вчителя філологічних спеціальностей до соціокультурного досвіду, що створює передумови для формування його дидактичної компетентності.

Мета публікації- розробити зміст культурологічного складника у процесі фахової підготовки майбутніх учителів філологічних спеціальностей.

Дидактична компетентність уможливлює трансляцію соціокультурних знань відповідно до міри реалізації загальнокультурного потенціалу вчителя у різних видах його педагогічної діяльності.

Культурологічна компонента дидактичної компетентності майбутніх учителів філологічних спеціальностей: розкриває закономірності засвоєння знань, умінь і навичок і формування переконань і досвіду (особистісного на етапі інтеріоризації ціннісних орієнтацій); визначає обсяг і структуру змісту культурологічної освіти; удосконалює методи й організаційні форми навчання під час оволодіння навчальним матеріалом на курсах відповідного культурологічного спрямування; виховує особистість шляхом впливу навчального процесу того, хто навчається.

Інтегративна функція культурологічної компоненти у структурі дидактичної компетентності майбутніх учителів філологічних спеціальностейзабезпечує цілісність процесу розвитку і використання особистістюінноваційно-акмеологічної культури [4]. 
Отже, головною функцією культурологічної компоненти $є$ забезпечення продуктивного характеру дидактичної компетентності майбутніх учителів філологічнихспеціальностей.

Розроблення культурологічної компоненти дидактичної компетентності майбутніх учителів філологічних спеціальностей передбачає розвиток:

1) аксіологічного рівня, що передбачає засвоєння основних ціннісно-смислових і нормативно-регулятивних настанов світових і національних культур, спрямоване на уведення особистості до соціокультурної дійсності, побудованої на основі ціннісних орієнтацій, надання підтримки у виборі індивідуально значимої аксіологічної системи в ситуаціях постійної зміни значущих цінностей;

2) комунікативного рівня, який передбачає оволодіння формами й засобами соціальної комунікації, провідними принципами здійснення діалогового (полілогового) спілкування шляхом оволодіння основними його механізмами й кодами в соціумі, орієнтованими на забезпечення процесів міжособистісної взаємодії в навчально-виховному процесі;

3) суб'єктно-інтеріоризаційного рівня, який передбачає оволодіння способами саморегуляції особистісного і фахового розвитку, засобами продуктивної активності, методами самостійного прирощення знання, як загальнокультурного, так і фахового, у їх спрямованості на соціокультурне становлення професійного досвіду особистості.

У методологічному плані розуміння дидактичної компетентності як інтегрованого цілого дозволяє спроектувати універсальний культурний механізм соціального успадкування вироблених способів діяльності і сформованих сутнісних сил людини, на педагогічну площину і стверджувати, що формування вчителя як суб'єкта фахової культури забезпечується процесом розпредмечення (пізнання культурного в індивідуальній формі); опредмечення (реалізація культурологічного змісту в індивідуальній діяльності особистості). Зазначений механізм передбачає діалектичний взаємозв'язок оволодіння досвідом фахової культури, опредмеченого в загальнокультурних знаннях, цінностях, спроектованих у площину педагогічної діяльності, та їі розпредмечення, тобто розкриття особистісного смислу, оволодіння способами теоретичної і практичної творчої діяльності задля реформування педагогічного середовища, системи педагогічних цінностей.

Організаційно-методична система формування культурологічних цінностей майбутніх учителів філологічних спеціальностей грунтується на осмисленні етичних соціокультурних альтернатив як способів визначення стратегій життєдіяльності людини, постановки та розв'язання моральних колізій людського буття у їх історикокультурному вимірі. У процесі актуалізації й розвитку аксіологічного потенціалу культурологічної освіти майбутніх учителів філологічних спеціальностей формується система культурологічних цінностей студентів, що забезпечує функціонування мотиваційного складника самовизначення майбутніх учителів філологічних спеціальностей у просторі національної і світової культури й конструювання педагогічної діяльності на аксіологічних засадах.

Дидактичний супровід дозволяє виявити рівень розвитку емпатії i рівень усвідомлення екзистенційних смислів навчального тексту соціокультурного спрямування на основі його емоційного сприйняття.

Повноцінність розуміння тексту культури визначається здатністю відчувати його емоційний настрій передовсім вираження того, що міститься в зображенні, його узагальненому образі. Емпатія як уявне перенесення себе в думках, почуттях і діях іншого і структурування світу за його зразком становить психологічний механізм, який 
забезпечує процес співпереживання особистості, визначає ефект присутності, співучасті в подіях художнього твору. У процесі занурення в авторську модель дійсності усвідомлюється цінність культурних смислів для адресата культурного тексту.

Екзистенційна інтерпретація становить особисту відповідь на питання, 3 яким текст культури звертається до читача, яке можливе лише за умови діалогізації, реалізації власного ставлення до соціокультурної дійсності. Здатність усвідомлювати екзистенційні смисли тексту свідчить про сформованість емоційно-ціннісного ставлення до явищ соціокультурної дійсності, а отже, інтеріоризацію аксіологічних цінностей. Основними показниками рівня розвитку емоційно-ціннісного ставлення до тексту культури визначено: адекватність визначення основної емоційної модальності; оригінальність емоційних характеристик тексту культури; повноцінність відчуття екзистенціального сенсу тексту.

Результати діагностування системи аксіологічних цінностей майбутніх учителів філологічних спеціальностей покладено в основу чинників методичної організації культурологічної освіти студентів у вищій педагогічній школі у процесі формування дидактичної компетентності: 1) особистісна орієнтація культурологічної освіти майбутнього вчителя філологічних спеціальностей; 2) компаративізація культурологічного аналізу/ герменетика смислів текстів соціокультурного спрямування; 3) діалогізація як умова формування емоційно-ціннісного ставлення студентів філологічних спеціальностей до соціокультурної дійсності.

Організаційно-методичне забезпечення культурологічного складника у змісті культурологічної освіти у процесі формування дидактичної компетентності майбутніх учителів філологічних спеціальностей передбачає застосування способів організації педагогічного процесу на основі визнання пріоритетності формування ціннісної свідомості студента філологічних спеціальностей: принципу єдності особистісного і фахового розвитку вчителя (ознайомлення майбутніх філологів із системою ціннісних уявлень культури, сутністю процесу набуття особистісних смислів і цінностей; розуміння механізмів ціннісного ставлення до життєдіяльності, механізмів його формування, орієнтації в галузі загальнокультурних цінностей, стійкості особистісної системи цінностей).

Отже, культурологічна освіта у процесі формування дидактичної компетентності майбутніх учителів філологічних спеціальностей набуває цінності для студента, якщо вона становить особистісну значимість. Окреслене дозволяє розв'язати суперечність сучасної вищої освіти майбутніх філологів між поданням культурологічно значущої навчальної інформації у межах нормативної частини циклу гуманітарної, психологопедагогічної і професійної науково-предметної підготовки як засобу задоволення тих чи тих пізнавальних потреб $\mathrm{i}$ як процесу й результату оволодіння студентами універсальними основами загальнолюдської культури на засадах інтегральності, аксіологічності, антропологічності, полікультурності та фахового спрямування й подальшої інтеріоризації аксіологічних цінностей. Розв'язання окресленої суперечності уможливить суттєво зменшити відсоток студентів філологічних спеціальностей із поверхневою ерудицією в межах культурологічної навчальної інформації.

Задля подолання труднощів студентів філологічних спеціальностей у плані виокремлення й об'єктивізації ціннісних смислів тих чи тих культурних явищ пропозицією було застосування експериментального чинника- компаративізації культурологічного аналізу смислів текстів соціокультурного спрямування; художніх текстів як порівняльно-історичного методу в гуманітарних науках, заснованого на зіставленні культурних характеристик $[3 ; 5 ; 6 ; 7]$. Компаративний метод спрямовує їх 
на аналіз принципових смислів життєдіяльності людини в соціокультурному просторі; передбачає зіставлення досліджуваної культури 3 попередніми, синхронними або наступними в генетичному ряді національними культурами. У цілому компаративний метод відображає тенденцію сучасної епістемологічної парадигми до нелінійного мислення, компліментарності істини, зіткнення смислових альтернатив, є адекватним соціокультурним процесам із їх динамікою взаємовпливу і взаємодії традицій.

Компаративний аналіз у культурологічній освіті у процесі формування дидактичної компетентності майбутнього вчителя філологічних спеціальностей використано як експериментальний чинник, що сприяє виокремленню й об'єктивному аналізу студентом аксіологічних смислів текстів культури. Зіставлення трактування різними культурами загальної соціокультурної проблеми полегшує виокремлення провідної аксіологічної проблеми тієї чи тієї культури; дозволяє визначити тотожне і відмінне в різних культурах; стимулює усвідомлення альтернативності смислів людської життєдіяльності, виводить майбутніх фахівців на рівень осмислення власної соціокультурної позиції. Наводимо приклади компаративних методик, використовуваних під час викладання курсу «Лінгвістичний аналіз тексту» мовознавчого блоку фахової підготовки майбутніх філологів:

1. Завдання: сформулювати об'єкт і предмет, проблему дослідження наведених текстів у контексті аналогічних досліджень, а також відповідно до змісту гуманітарної підготовки майбутніх учителів філологічних спеціальностей; змісту навчання гуманітарних предметів у загальноосвітніх закладах:

I. Я пішла до літа у гості. Літо ж заховалось за осінь. I сказала строго зима, Що для мене літа нема... Підійшла до щзастя несміло. На краєчок лави присіла. А воно - чуже, весняне - Навіть не впізнало мене... Ми так давно не святкували літа. Мій гість сказав: «Знайшла за чим жаліти? Зима - свята, а осінь - золота ... А літо від лукавого. Отак!»

II. А з кожним роком холодніш Нам зими і коротші весни. I не встигає тануть сніг В короткій гривці поетеси... I од сніжинки до сніжинки Сильніш загорненість у шаль Плечей старіючої жінки. О листопад! Пора утрат... А ще болить. А ще ж ивіте! Згоряє $і$ зіходить димом. Я говорю на сотні тем, Але мовчу - на ту, єдину... Що ж, домовчу. Тепер уже Мовчать лишилось недалеко... I синє сонечко любові зайде, закотиться за шаль... I коли стане білим-біле Усе: $i$ сад мій, $і$ волоссяСкажу: "А я тебе любила. Але тоді була вже осінь...» I все лишиться при мені. I синє сонечко любові Крізь домовину, землю, сніг - синітиме наївно, палко $i$ (то вжевесняний мотив) - засвічуватиме фіалки, печальні квіточки ијноти.

III. Даремно питати у квіту Про зиму. Яка там зима! Душа його віддана літу, А літа зимою нема...Розквітлася квітка - $i$ квітне. Їй любо синіть чи жовтіть. I стільки у літечка - літа! I стільки життя у житті!

2. Визначте ціннісні домінанти української й російської культур, представлені в поетичних текстах:

А) У ластівки - ластовенятко, / В шовковиці- иовковенятко,/ В гаю у стежки стеженятко, / У хмари в небі-хмаренятко, / В зорі над садом- зоренятко: / Вже народилися, / Лиш зажурилися / Старезна скеля над урвищем/ Та дуба всохле стовбурище (М. Вінграновський);

Б) Кузнечик

Крылышкуя золотописьмом / Тончайших жил, / Кузнечик в кузов пуза уложил / Прибрежных много трав и вер. / «Пинь, пинь, пинь!»- тарарахнул зинзивер. / О, лебедиво! / О, озари! (В. Хлебников). 
3. Прочитайте наведені хоку (хайку), одна з яких у кожному варіанті є професійним перекладом творів Кобаяссі Ісса українською мовою, а друга - «деформованим» перекладом. Знайдіть оригінал і спробуйте пояснити, що саме в стилістиці або змісті допомогло визначити оригінальний твір як текст японської культури.

А) Тремтить Росина. / Нехай життя наше - / теж як крапелька, але ...

Б) Тремтить Росина. / Життя наше / Теж у крапельиі.

3. Визначте особливості ідіостилю жанру хоку японського й українського авторів:

A) Наші голоси - / Скорбні двійники / Мов крила вітру в степу;

Б) Навколо - хмари і лиховій. / Метелик сідає на / Білу пелюстку квітки. / I тремтить своїми прозорими крильиятами.

4. Здійсніть лінгвістичний аналіз тексту. Визначте, до якого напряму в мистецтві належить текстовий фрагмент. Доведіть думку.

На місто насувалась гроза. Поважно й поволі повзла вона чорним драконом $i$, зрідка блимаючи своїми вогненними очима, грізно й незадоволено буркотіла. Весняне сонце, шуо весело посміхалося з голубої бані й кокетливо шпурляло на брук свої золоті проміння, остаточно зачарувало всіх: святкова публіка весело пливла по асфальтових тротуарах $i$, имигаючи своїм строкатим вбранням, безтурботно шелестіла симпатичним, міським гомоном.

Але от гроза нарешті доповзла і дракон розкинув свої крила над околицею. I тоді якось враз, блискавично, над костьолом повисли темно-сині шмаття авангардних хмар і колись дальній грім уже забуркотів чітко, голосно і недвозначно. Якось враз над городом знялась курява й завертівся передгрозовий вихор. Закрапав рідкий, краплистий дощ (М. Хвильовий).

5. Перебуваючи на історичній землі, Т.Шевченко виконав кілька етюдів: «Богданові руїни в Суботові», «Богданова церква в Суботові», краєвид Чигирина із Суботівського шляху; за цими враженнями і спостереженнями було написано вірші «Розрита могила», «Чигирине, Чигирине...».

Завдання. Окресліть історичну проблематику цих творів у взаємозв'язку мистецтва й літератури.

6. Т. Шевченко був першим із митців, яких було залучено до створеної в 1845 р. Археографічної комісії в Києві. Об’їхавши Полтавщину, Чернігівщину, Київщину, Волинь та Поділля, зарисовуючи пам'ятки мистецької старовини, митець створив не тільки цінний документальний матеріал, але й засвідчує своєю спадщиною розуміння філософічності творів старої культури.

Будучи академіком гравірування на міді, митець поряд із традиційними класичними темами виконує низку гравюр на історично-побутову тематику (Верба», «Старець на кладовищі», «Сама собі в хаті господиня», «Дві дівчини», «Сонна жінка»).

Праці, за які Т. Шевченко дістає академічні відзнаки, є достатньо далекими від класицистичних ідеалів «Карла Великого». «Борець» (1838), «Хлопчик, що ділиться хлібом із собакою» (1840), «Циганка» (1841) мають окреслений стиль романтичного побутовизму. Не без упливу В. Штенберга у Шевченка (1844) народжується замисел «Живописної України», що мала створити за задумом тритомний альбом рисунків із текстами провідних українознавців тієї доби.

Завдання. Порівняйте мистецьку спадщину на історико-побутову тематику й художню (період романтизму), доведіть думку Євгена Маланюка про те, що «живописна Україна» Шевченка відображена в романтичних творах, які мали завжди конкретне реальне втілення, реалізуючи тісний взаємозв'язок із краєвидом, дійсністю, історією й, нарешті, долею народу». 
Однією $з$ особливостей представленої технології компаративного аналізу є спостереження над автентичним текстом культури як емоційно насиченого i максимально наповненого унікальним ціннісним змістом, що значною мірою мінімізує обсяг часу, відведеного на вивчення дисциплін нормативної частини професійної науково-предметної підготовки майбутніх учителів філологічних спеціальностей виключно за підручниками, які містять понятійно-фактичну інформацію й орієнтовані на одну несуперечливу авторську концепцію.

Пропозицією $\epsilon$ організація роботи 3 першоджерелами соціокультурної інформації, метою якої є розвиток культури читання, педагогічна підтримка студентів у їхньому самовизначенні у просторі соціокультурних цінностей.

Отже, діалектика соціокультурного i фахового полягає в тому, що загальнокультурний розвиток особистості зумовлює вибір професії педагога i підготовку до її здійснення. У подальшому сам цей вибір і безпосередня педагогічна діяльність визначають шляхи культурного розвитку фахівця. Розуміння соціокультурних знань як функціонально необхідних учителеві будь-якої фахової спеціалізації, визнання дидактичної компетентності вчителя філологічних спеціальностей чинником розвитку учнів завдяки вираженим критеріям професійної значимості й наявності механізмів впливу, надає підстави стверджувати, що культурологічну підготовку вчителя варто розглядати як провідний складник його педагогічної освіти.

На подальший розгляд заслуговує розроблення компаративних методик лінгвістичного аналізу тексту у змісті підготовки майбутніх філологів, зокремавідповідно до жанрової специфіки (мініатюра, гумореска / усмішка; рубаї; аннали (літописи); сонет; притча; епістола тощо) в соціокультурному контексті.

\section{Література}

1. Гончаренко С. У. Український педагогічний словник / [авт-уклад. С. У. Гончаренко]. - К. : Либідь, 1997. - 367 с. 2. Енциклопедія освіти : [гол. ред. В. Г. Кремень]. - К. : Юрінком Інтер, 2008. - 1040 с. З. Жила С. В. Теорія і практика вивчення української літератури у взаємозв'язках із різними видами мистецтв у старших класах загальноосвітньої школи : дис. ... доктора пед. наук; 13.00 .02 / Жила Світлана Олексіївна. - К., 2004. - 575 с. 4. Кузьмина Н. В. Акмеологическая теория повышения качества подготовки специалистов образования/ Нина Васильевна Кузьмина. - М. : Исслед. центр проблем качества подготовки специалистов, 2001. 144 с. 5. Лингвистический энциклопедический словарь / гл. ред. В. Н. Ярцева. - М. : Сов. Энциклопедия, 1990. - 685 с. 6. Философский словарь / под ред. И. Т. Фролова. [5-е изд.]. - М. : Политиздат, 1987. - 590 с. 7. Шевнюк О. Л. Теорія і практика культурологічної освіти майбутніх учителів у вищій школі : дис. ... доктора пед. наук; 13.00.04 / Шевнюк Олена Леонідівна. - К., 2004. - 473 с.

\section{СЕМІОТИЧНИЙ ПЦХІД У ПРОФЕСІЙНІЙ ПЦГОТОВЦ МАЙБУТНІХ УЧИТЕЛІВ МУЗИЧНОГО МИСТЕЦТВА ДО ВОКАЛЬНО-ПЕДАГОГІЧНОЇ ДІЯЛЬНОСТІ}

Овчаренко Н. А. Семіотичний підхід у професійній підготовці майбутніх учителів музичного мистецтва до вокально-педагогічної діяльності.

У статті розглядається актуальна проблема реалізації семіотичного підходу у професійній підготовці майбутніх учителів музичного мистецтва. Здійснено аналіз науково-теоретичного досвіду щодо визначення базових понять дослідження та 